\title{
Antibodies to Leishmania spp. in domestic felines
}

\author{
Anticorpos anti-Leishmania spp. em felinos domésticos
}

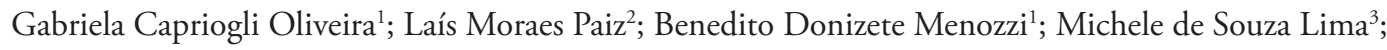 \\ Carla Cristina Guimarães de Moraes ${ }^{3}$; Helio Langoni ${ }^{1 *}$
}

\begin{abstract}
${ }^{1}$ Laboratório de Diagnóstico de Zoonoses, Departamento de Higiene Veterinária e Saúde Pública, Faculdade de Medicina Veterinária e Zootecnia - FMVZ, Universidade Estadual Paulista "Júlio de Mesquita Filho" - UNESP, Câmpus de Botucatu, Botucatu, SP, Brasil

${ }^{2}$ Laboratório de Epidemiologia, Departamento de Saúde Coletiva, Faculdade de Ciências Médicas, Universidade Estadual de Campinas - UNICAMP, Campinas, SP, Brasil

${ }^{3}$ Instituto de Medicina Veterinária, Universidade Federal do Pará - UFPA, Campus de Castanhal, Castanhal, PA, Brasil
\end{abstract}

Received February 11, 2015

Accepted May 21, 2015

\begin{abstract}
Leishmaniasis is a vector-borne zoonotic disease caused by protozoa in the genus Leishmania, typical of rural and peri-urban environments. The causative agent of American visceral leishmaniasis is Leishmania (Leishmania) infantum chagasi and the main insect vector in Brazil is Lutzomyia longipalpis. Dogs (Canis familiaris) are important in the transmission of the disease, as a reservoir closely related to humans and an infection source for phlebotomine vectors. Since 1990, an increasing number of feline leishmaniasis cases have been reported, suggesting that domestic cats (Felis catus) might be involved in the epidemiology of the disease. The present study analyzed the prevalence of anti-Leishmania spp. antibodies in naturally infected domestic cats from various neighborhoods in the municipality of Belém, Pará, Brazil, using the indirect immunofluorescence assay (IFA) and the direct agglutination test (DAT). Among the 443 samples tested, $18(4.06 \%)$ presented positive reactions in the IFA. The observed titers were 40 IU in $4.97 \%$ of the samples and 80 IU in $0.90 \%$. In the DAT test, positive results were found in $25(5.64 \%)$ of the samples. The observed titers were also $40 \mathrm{IU}$ $(4.97 \%)$ and $80 \mathrm{IU}(0.68 \%)$. The agreement rate between the two tests was considered low (Kappa coefficient $=0.10)$.
\end{abstract}

Keywords: Indirect immunofluorescence assay, direct agglutination test, leishmaniasis, cats.

\section{Resumo}

As leishmanioses são zoonoses vetoriais causadas por protozoários do gênero Leishmania, características de ambientes rurais e periurbanos. A leishmaniose visceral americana (LVA) é causada pela Leishmania (Leishmania) infantum chagasi, cujo principal vetor no Brasil é Lutzomyia longipalpis. O cão (Canis familiaris) possui papel ativo na transmissão da doença, pois é um reservatório muito próximo do humano e uma fonte de infecção para o flebotomíneo. O aumento do número de casos de leishmaniose felina, descritos na literatura a partir de 1990, sugere que gatos também podem atuar na epidemiologia dessa enfermidade. O presente estudo avaliou a prevalência de anticorpos anti-Leishmania spp. em gatos domésticos (Felis catus) de diferentes bairros do Município de Belém, Pará (PA), pela Reaçáo de Imunofluorescência Indireta (RIFI) e pelo Teste de Aglutinação Direta (TAD), utilizando-se como ponto de corte o título de 40 UI. Entre os 443 gatos estudados, $18(4,06 \%)$ apresentaram reação sorológica positiva na RIFI. Os títulos observados foram de $40 \mathrm{UI}$ em $0,90 \%$. No TAD, foi encontrada positividade em 25 (5,64\%) animais. Os títulos observados foram de 40 UI, em 4,97\% dos gatos, e 80 UI, em 0,68\%. A concordância entre os testes foi considerada baixa (coeficiente Kappa: 0,10).

Palavras-chave: Reação de imunofluorescência indireta, teste de aglutinação direta, leishmaniose, gatos.

Leishmaniasis is a vector-borne zoonotic disease caused by protozoa of the genus Leishmania, Kinetoplastida order, Trypanosomatidae family, and transmitted by phlebotomine species, causing tegumental and visceral injuries (ROSA, 2009). In the parasitic life cycle, promastigotes are found in the vector and amastigotes are found in the infected host tissues (BANETH, 2006).

*Corresponding author: Hélio Langoni. Faculdade de Medicina Veterinária e Zootecnia - FMVZ, Universidade Estadual Paulista - UNESP, Distrito de Rubião Junior, s/n, CEP 18618-970, Botucatu, SP, Brasil.

e-mail: hlangoni@fmvz.unesp.br
Leishmaniasis is typical of rural and peri-urban environments. Domestic and wild mammals can be infected; humans are considered accidental hosts of the protozoa (CURI et al., 2006).

The dog (Canis familiaris) has an active role in the transmission of the disease as an asymptomatic reservoir that is closely related to humans and an infection source to phlebotomine vectors (COURTENAY et al., 2002).

American visceral leishmaniasis is caused by Leishmania (Leishmania) infantum chagasi, and is a serious public health problem in Brazil owing to the wide geographical distribution 
of the disease, high incidence, and the ability to lead to a severe clinical form that may cause death (SCHALLIG et al., 2002). The predominant vector found in Brazil is Lutzomyia longipalpis (DEANE \& DEANE, 1962).

Initially, dogs were considered the only urban reservoirs of Leishmania (Leishmania) infantum chagasi in Brazil. However, the increasing number of cases in domestic cats suggests that they also play an important role in the disease epidemiology (MANCIANTI, 2004). A natural infection in a domestic feline (Felis catus) by Leishmania spp. was first reported in 1912 in Algeria in a four-month-old animal that lived with a dog and a child, both also infected with the visceral form of the disease (SERGENT et al., 1912). The diagnosis was based on the presence of the amastigotes form of the parasite in the bone marrow, but the species was not identified.

Serological techniques are now commonly used to diagnose leishmaniasis, and are considered indispensable tools for epidemiological studies (SILVEIRA, 2010). Indirect immunofluorescence assay (IFA), direct agglutination test (DAT), and enzyme-linked immunosorbent assay (ELISA) are the main serological diagnostic tests, and others include immunohistochemistry techniques, isolation of the parasite in culture, direct demonstration using smears, polymerase chain reaction (PCR), and the rapid immunochromatographic test (standardized for dogs). Each test has positive and negative intrinsic technical characteristics.

The IFA is an antibody detection test that uses intact parasites as antigens (ALVES \& BEVILACQUA, 2004). Its main limitations are the cost of using an immunofluorescence microscope and the laborious serial dilutions necessary for titration. Furthermore, serological cross-reactivity can occur with other antigens (LUCIANO et al., 2009).

The DAT is simple and does not require specialized equipment. Its limitations include the long incubation period, difficulties in standardization, and the need for high-quality antigens (MOHEBALI et al., 2011).

Deane \& Deane (1937) have reported human cases of American visceral leishmaniasis in Pará, Brazil. From 1995-2000, Feitosa et al. (2012) identified phlebotomine species in rural and urban sites in Santarém, Pará, and the vector Lutzomyia longipalpis was abundant.

The city of Belém is an area of sporadic transmission of visceral leishmaniasis according to the Brazilian Ministry of Health (BRASIL, 2007). An entomological study conducted between 2009 and 2011 identified six species of epidemiologically important vectors for the transmission of cutaneous leishmaniasis in that region (FERREIRA et al., 2014).

Garcez et al. (2010) carried out entomological captures in tracking dogs during the summer and winter in the Amazonian city of Juriti, located $848 \mathrm{~km}$ from the city of Belém. They found synanthropic sandflies, mainly Lutzomyia longipalpis, in the environment. In addition, serological surveys showed a high frequency of seropositivity for LVC in the neighborhoods of Juriti, Pará (SCHWANKE et al., 2014).

An investigation of leishmaniasis in the domestic feline in Belém, based on reports of natural infections across Brazil and worldwide, suggests a possible epidemiological role of the species for leishmaniasis transmission. Furthermore, Belém is a surveillance region, and at one point, 34.9\% of leishmaniasis cases in Brazil occurred in the Northern Region (COSTA, 2005).

The focus of this study was to evaluate the presence of Leishmania (L.) $i$. chagasi antibodies in domestic felines from the municipality of Belém, Brazil using the IFA and DAT tests, and to estimate the association between the serological results and epidemiological variables such as gender, age, breed, and provenance of animals.

\section{Materials and Methods}

\section{Geographic area of interest}

Feline serum samples were collected from Belém, Pará, Brazil. The municipality is $1,064.918 \mathrm{~km}^{2}$ with 39 islands located in the Atlantic Ocean. The municipality has a total of 75 official neighborhoods, spread over eight administrative districts. The weather is equatorial, permanently humid, influenced by the presence of the Amazon forest, with abundant rain especially between January and May. The annual average temperature varies from $26^{\circ} \mathrm{C}$ to $32{ }^{\circ} \mathrm{C}$ and the rainfall is around $3000 \mathrm{~mm} /$ year.

\section{Animals}

To estimate the number of animals, data from the most recent anti-rabies vaccination campaign organized by the Center for Zoonosis Control (CZC) of Belém were used; there is no feline census data for the municipality. The animals represented eight different neighborhoods in the city. Using this data, sampling was performed assuming an expected prevalence of 50\% and $95 \%$ confidence levels. The simple random sample formula, proposed by Thrusfield (2007), was used to estimate the total number of animals, 443. During sampling, an epidemiological questionnaire was used to obtain data regarding the gender, age, breed, and free access to streets for the animals.

\section{Sample collection}

The blood samples were obtained by jugular or cephalic venipuncture using disposable syringes and needles, and 3-5 mL of blood was collected in glass tubes without EDTA. The samples were centrifuged at $1600 \times g$ for 10 minutes and the serum was immediatly placed plastic microtubes, properly labeled, and stored at $-20^{\circ} \mathrm{C}$ until the execution of serological tests carried out at the Núcleo de Pesquisas em Zoonoses (NUPEZO), Departamento de Higiene Veterinária e Saúde Pública da Faculdade de Medicina Veterinária e Zootecnia da UNESP, Campus of Botucatu, Brazil.

\section{Indirect immunofluorescence assay (IFA-IgG)}

The antigen for sensitization of the slides was produced with using L. major promastigotes kept in tubes containing $9 \mathrm{~mL}$ of liver infusion broth and tryptose medium and $5 \mathrm{~mL}$ of Novy-McNeal-Nicolle medium. After drying, the slides were kept at $-20{ }^{\circ} \mathrm{C}$ until use. 
The Leishmania (L.) i. chagasi antibodies were studied using IFA (CAMARGO, 1974) for serial serum dilutions of 1:40, $1: 80,1: 160,1: 320$, and 1:640. This process was performed in microplates, using $190 \mu \mathrm{L}$ of phosphate-buffered saline (PBS) $(\mathrm{pH} 7.2)$ to begin the serial dilution with $10 \mu \mathrm{L}$ of the serum sample in the first well (1:20 dilution). Subsequently, $100 \mu \mathrm{L}$ of PBS was added into the next five wells, pipetting a $100-\mu \mathrm{L}$ volume from the first dilution into the next well (after homogenization), until reaching the fifth well, and the last $100-\mu \mathrm{L}$ volume was discarded. This procedure was repeated with positive and negative control serum samples. Each serum dilution $(10 \mu \mathrm{L})$ was pipetted into the slide wells, including the positive and negative controls. The slides were incubated inside a moist chamber at $37^{\circ} \mathrm{C}$, for 30 minutes. Afterwards, they were washed twice with PBS for 10 minutes and dried in incubator at $37^{\circ} \mathrm{C}$.

Anti-immunoglobulin $\mathrm{G}$ ( $\mathrm{IgG}$ ) specific to cats, conjugated with the fluorescein isothiocyanate, was diluted according to the manufacturer's instructions, using Evans Blue solution with PBS (1:5) and adding $10 \mu \mathrm{L}$ to each dilution on the slides.

The slides were again incubated for 30 minutes at $37{ }^{\circ} \mathrm{C}$ in a moist chamber, washed with PBS, dried in the incubator, assembled with buffered glycerol ( $\mathrm{pH} 8.5$ ), and covered with coverslips. The slides were examined using an immunofluorescence microscope (magnification of $40 \times$ ). After reading the controls, the highest dilution of the serum for which complete fluorescence occurred at the border of at least $50 \%$ of the promastigotes was considered the cut-off point, equal or superior to 40 IU.

\section{Direct Agglutination Test (DAT)}

The DAT was performed according to the methods of Garcez et al. (1997), with some modifications. The promastigotes form of $L$. major was cultured in liver infusion broth + tryptose and Novy-McNeal-Nicolle media until reaching the stationary phase of growth. The parasites then were washed five times with Locke solution. The sediment was suspended at 1/20 in Locke solution containing $0.4 \%$ of trypsin and incubated for 45 minutes at $37^{\circ} \mathrm{C}$. The parasites were washed again and suspended in a $2 \times 10^{8}$ promastigotes $/ \mathrm{mL}$ solution. An equal volume of formaldehyde $2 \%$ was added to the Locke solution and the suspension was kept at $4{ }^{\circ} \mathrm{C}$ overnight. The parasites were washed three times with physiological solution and resuspended in physiological solution containing $0.02 \%$ of Coomassie Brilliant Blue pigment to reach $1 \times 10^{8}$ promastigotes $/ \mathrm{mL}$, keeping them active during and after 90 minutes of centrifugation. They were then washed three times with physiological solution. The concentration was adjusted to $1 \times 10^{8}$ promastigotes $/ \mathrm{mL}$ using physiological solution containing
$1 \%$ formaldehyde and samples were kept at $4{ }^{\circ} \mathrm{C}$ in amber bottles until their use as antigens.

The sera were first diluted 1:20 in physiological solution containing $1 \%$ fetal bovine serum and $0.7 \%$ of 2 -mercaptoethanol into $\mathrm{V}$-shaped wells in microplates and incubated for one hour at environmental temperature. An equal volume of antigen suspension was then added and the solution was kept at room temperature overnight. The positive and negative control serum samples were used as controls. The cut-off point was 40 IU (BRASIL, 2011).

\section{Statistical analysis}

Frequency distributions were analyzed. The chi-square and Fisher's exact tests (SAS, 2011) were used to test the association between risk factors and seropositivity, at a 95\% confidence level. The Kappa coefficient was used to determine the agreement rate between the IFA and DAT.

\section{Results}

Of the 443 serum samples, 18 (4.06\%) were positive based on the IFA, 13 (2.94\%) of which were labelled 40 IU and $4(0.90 \%)$ were $80 \mathrm{IU}$. One of the samples was not included owing to an insufficient serum volume.

In the DAT, 25 (5.64\%) animals tested positive, $4.97 \%$ with 40 IU labels and $0.68 \%$ with 80 IU.

Of the 425 negative animals based on the IFA, 403 were also negative according to the DAT. Of 18 positive samples identified in the IFA, only three were also positive according to the DAT. This indicated that the agreement between the tests was low $($ Kappa coefficient $=0.10$; Fisher's Exact Test $P=0,0813)($ Table 1$)$.

In a comparison of the observed titers, 19 of the animals that tested negative using the IFA were 40 IU in the DAT and only three were 80 IU label. Twelve cats were negative in the DAT and of 13 cats labelled 40 IU in the IFA, only one was 40 IU in the DAT. Of four animals with the 80 IU label in the IFA, two were negative in the DAT and the other two were labelled $40 \mathrm{IU}$.

In the epidemiological analysis, among the 438 animals, $76.94 \%$ had no defined breed, $22.37 \%$ were Siamese, and $0.68 \%$ were Persian. With respect to age, $80.59 \%$ were young ( 0 to 3 years) and the rest were adults ( 4 to 18 years). Females represented $60.50 \%$ of the individuals and $39.50 \%$ were male.

For walking habits, $88.36 \%$ of animals stayed home during the day. Origin was defined as the neighborhood from which they came, and 5.71\% were from downtown Belém, 10.50\% from Benguí, 16.67\% from Entroncamento, 26.94\% from Guamá,

Table 1. Comparison between the serological results of the indirect immunofluorescence assay (IFA) and direct agglutination test (DAT) in domestic cats, from Belém, Pará, Brazil.

\begin{tabular}{ccccc}
\hline \multirow{2}{*}{ DAT } & & IFA & Total & \\
\cline { 2 - 4 } & Positive & Negative & $\mathbf{2 5}$ \\
Positive & 3 & 22 & $\mathbf{4 1 8}$ \\
Negative & 15 & 403 & $\mathbf{4 2 5}$ & $\mathbf{4 4 3}$ \\
Total & $\mathbf{1 8}$ & & \\
\hline
\end{tabular}

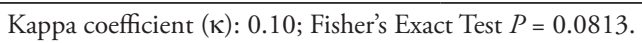


Table 2. Association between variables: breed, age, gender, in-residence stay, and animal origin and the serological results for leishmaniasis using the IFA. Botucatu-SP, 2014.

\begin{tabular}{llll}
\hline \multicolumn{1}{c}{ Variables } & $\mathbf{N}^{\mathbf{a}}$ & $\begin{array}{c}\text { Positive Animals } \\
\mathbf{N}^{\mathbf{b}}(\%)^{\mathbf{c}}\end{array}$ & P-Value \\
\hline Breed & & & $0.45^{\mathrm{d}}$ \\
$\quad$ Undefined & 337 & $15(3.42)$ & \\
Persian & 3 & 0 & \\
Siamese & 98 & $2(0.6)$ &
\end{tabular}

Age

Young

Adults

\section{Gender}

Male

Female

Without outdoor access

$\begin{array}{lll}\text { Yes } & 51 & 3(0.68) \\ \text { No } & 387 & 14(3.20)\end{array}$

\section{Origin}

$\begin{array}{lll}\text { Downtown } & 25 & 2(0.46) \\ \text { Benguí } & 46 & 2(0.46) \\ \text { Entroncamento } & 73 & 2(0.46) \\ \text { Guamá } & 118 & 4(0.91) \\ \text { Administrative District of } & 38 & 1(0.23) \\ \text { Icoaraci } & & \\ \text { Ilha do Mosqueiro } & 2 & 0 \\ \text { Outeiro } & 15 & 0 \\ \text { Sacramento } & 111 & 6(1.37)\end{array}$

Key: ${ }^{2}$ Number of animals with data for each variable. ${ }^{b}$ Frequency of reagents based on the analyzed variable. ${ }^{c}$ Percentage of positive animals for the antibodies based on the IFA when labelled $\geq 40 \mathrm{IU}$; $P$ : value of P for $\alpha=5 \%$. ${ }^{\mathrm{d}}$ Fisher's exact test. ${ }^{e}$ Chi-square test.

25.34\% from Sacramento, 8.68\% the Administrative District of Icoaraci, 2.74\% from Ilha do Mosqueiro, and 3.42\% (15/438) from the Outeiro neighborhood.

Younger animals were slightly more likely to test positive in the IFA than older animals $(\mathrm{P}=0.05)$. The young animals demonstrated $3.88 \%$ (17/438) positivity, but no adults tested positive. No significant difference was observed for the other analyzed variables (Table 2 ).

\section{Discussion}

In Brazil, visceral leishmaniasis has been repeatedly reported in domestic cats (SAVANI et al., 2004; ROSSI, 2007; SILVA et al., 2008; NOÉ, 2008; COELHO et al., 2010; COSTA et al., 2010; MARODIN, 2011). These are primarily case studies of the occurrence of natural infections in cats. Few studies have examined seroprevalence.
In the present study, seroprevalence was $4.06 \%$ based on the IFA. This estimate was lower than the results presented by Rossi (2007), which showed a prevalence of $6.5 \%$ using the parasitological exam ELISA and IFA. Costa et al. (2010) observed $11.5 \%$ positivity using ELISA. However, the prevalence found in this study was higher than those reported by Bresciani et al. (2010) and Silveira (2010), which both used ELISA and obtained 3.5\% positivity. Figueiredo et al. (2009) also found lower values in a study focusing on Rio de Janeiro; they reported $2.4 \%$ positivity using ELISA.

The rate of positive results using the DAT was $5.64 \%$ in this study. Using the same diagnostic tests, $1.9 \%$ positivity was found in Portugal for 36 animals (CARDOSO et al., 2010).

Caution is required when comparing the results of serological tests, owing primarily to poor standardization of antigens, dilution methods, and reagents. The development of standardized techniques for comparisons is necessary.

Regarding to the occurrence of visceral leishmaniasis in cats from the state of Pará, the estimate from this study is lower than those of Valadas et al. (2010), who found $23.2 \%$ positivity among 129 urban and rural dogs in the municipality of Santarém, and Schwanke et al. (2014), who found $14.8 \%$ (25/169) positivity in dogs from the Center for Zoonosis Control and 6\% (10/166) in pet dogs from Belém using sensitized IFA slides with Leishmania major-like promastigotes. However, no studies have considered cats or other susceptible species in this region.

A few studies have compared the use of IFA and DAT to diagnose leishmaniasis. A human study in Iran examining the anti-Leishmania spp. antibody rate detected 43 (70.5\%) positive patients using the DAT and 49 (80.3\%) using the IFA, showing substantial agreement between the tests (MIKAEILI et al., 2007), unlike the results found in the present study.

The IFA is recommended for the diagnosis of canine visceral leishmaniasis with good sensitivity and specificity. Uchôa et al. (2001) suggested that serological techniques must be used in combination with other diagnostic tests, such as direct PCR-based parasitological exams or the rapid immunochromatographic test.

For the diagnosis of canine visceral leishmaniasis, using L. major-like promastigotes as antigens may impair specificity owing to cross-reactions with other infectious agents. This occurs because different pathogens present similar L. major-like epitope features, especially for closely related species (ANDRADE et al., 2009).

The occurrence of cross-reactivity in serological tests is limited (FERRER et al., 1995). Some studies have reported that anti-Ehrlichia canis and Babesia canis antibodies also react with Leishmania spp. parasites (MANCIANTI et al., 1996; GOMES \& CORDEIRO, 2004).

Cross-reactivity between this antigen and other infectious agents has been demonstrated in several studies (VEXENAT et al., 1996; FERREIRA et al., 2007; ANDRADE et al., 2009), particularly for trypanosomes (FERREIRA et al., 2007).

Cross-reactions between infections in serological diagnoses primarily occurs when unpurified antigens are used. Despite reports of serological cross-reactivity between Leishmania spp. and Trypanosoma cruzi, little is known about the influence of other micro-organisms in the interpretation of results. (LONARDONI et al., 2006).

In the CVL, high antibody titers indicate an acute infection and potential transmission of the protozoan to vectors 
(QUINNELL et al., 2003); however, several studies have shown that this association does not apply to feline leishmaniasis cases. Other authors who have found low prevalence addition to the low titers in seroepidemiological studies have questioned the importance of cats as reservoirs of the disease, which reinforces the need for more studies on this subject (MARTÍN-SÁNCHEZ et al., 2007; DUARTE et al., 2010).

Kirkpatrick et al. (1984) demonstrated that intradermal inoculation of the promastigotes form of $L$. infantum in six cats leads to a significant rise in antibody titers only 16 weeks after the infection, when no parasite was found in the blood, bone marrow, spleen, or liver.

The results of Martín-Sánchez et al. (2007) suggest that a humoral response may have a protective role in cases of cats infected with Leishmania spp. Simóes-Mattos et al. (2005), after experimentally infecting a cat with $L$. braziliensis, did not find a correlation between the active lesions containing the parasite and positive serological results.

The low labels found in this study are similar to some previous results in felines, which show that feline antibody labels tend to be lower than those detected in canine visceral leishmaniasis cases (POLI et al., 2002; GRAMICCIA \& GRADONI, 2005; MAIA \& CAMPINO, 2011; GARRIDO, 2012). The low level or absence of antibodies may also be explained by reduced production of antibodies in felines relative to canids (MAIA et al., 2010; MAIA \& CAMPINO, 2011). Nevertheless, serological techniques are still used to diagnose feline leishmaniasis, but verification with other exams such as parasitological or molecular methods is necessary (GRAMICCIA, 2011) to improve the diagnostic sensitivity and specificity.

This study demonstrated natural $L$. (L.) i. chagasi infections in domestic felines from various neighborhoods in Belém, Brazil. It also emphasized that antibody research in the feline population is particularly important for public health, because cats, as well as dogs, are in close coexistence with humans, and their epidemiological role has not being properly clarified. The results indicate the need for new studies examining the use of the DAT as the diagnostic test for feline visceral leishmaniasis. Significant differences between the serological results with respect to the other analyzed variables were not observed.

\section{Acknowledgements}

The authors would like to acknowledge a collaboration with Professor José Carlos de Figueiredo Pantoja for the statistical analysis.

\section{References}

Alves WA, Bevilacqua PD. Quality of diagnosis of canine visceral Leishmaniasis in epidemiological surveys: an epidemic in Belo Horizonte, Minas Gerais, Brazil, 1993-1997. Cad Saude Publica 2004; 20(1): 259-265. http://dx.doi.org/10.1590/S0102-311X2004000100043. PMid:15029328.

Andrade AROD, Nunes VLB, Galati EAB, Arruda CCPD, Santos MFDC, Rocca MEG, et al. Epidemiological study on leishmaniasis in an area of environmental tourism and ecotourism, State of Mato Grosso do Sul, 2006-2007. Rev Soc Bras Med Trop 2009; 42(5): 488-493. http:// dx.doi.org/10.1590/S0037-86822009000500003. PMid:19967228.

Baneth G. Leishmaniases. In: Greene CE. Infectious diseases of the dog and cat. 5th ed. Missouri: Saunders Elsevier; 2006. p. 685-698.

Brasil. Ministério da Saúde, Secretaria de Vigilância em Saúde. Manual de vigilancia da leishmaniose tegumentar americana [online]. Brasília: Editora do Ministério da Saúde; 2007 [cited 2014 Feb 10]. Available from: http://bvsms.saude.gov.br/bvs/publicacoes/manual_vigilancia_ leishmaniose_tegumentar_americana.pdf

Brasil. Ministério da Saúde. Nota técnica no 48/2011-CGDT/DEVIT/SVS/ MS: esclarecimentos sobre o diagnóstico sorológico da leishmaniose visceral canina utilizado na rede pública de saúde [online]. Brasília; 2011 [cited 2014 Feb 10]. Available from: http://www.saude.ms.gov.br/controle/ ShowFile.php?id=113354

Bresciani KDS, Serrano ACM, Matos LVS, Savani ESMM, D’Auria SRN, Perri SHV, et al. Ocorrência de Leishmania spp. em felinos do município de Araçatuba, SP. Rev Bras Parasitol Vet 2010; 19(2): 127-129. http:// dx.doi.org/10.4322/rbpv.01902012. PMid:20624352.

Camargo ME. Introdução às técnicas de imunofluorescência. Rev Bras Patol Clin 1974; 10(1): 143-169.

Cardoso L, Lopes AP, Sherry K, Schallig H, Solano-Gallego L. Low seroprevalence of Leishmania infantum infection in cats from northern Portugal based on DAT and ELISA. Vet Parasitol 2010; 174(1-2): $37-$ 42. http://dx.doi.org/10.1016/j.vetpar.2010.08.022. PMid:20851524.

Coelho WMD, Lima VM, Amarante AF, Langoni H, Pereira VB, Abdelnour A, et al. Occurrence of Leishmania (Leishmania) chagasi in a domestic cat (Felis catus) in Andradina, São Paulo, Brazil: case report. Rev Bras Parasitol Vet 2010; 19(4): 256-258. http://dx.doi.org/10.1590/ S1984-29612010000400013. PMid:21184705.

Costa JML. Epidemiologia das leishmanioses no Brasil. Gaz Méd Bahia 2005; 75(1): 3-17.

Costa TAC, Rossi CN, Laurenti MD, Gomes AAD, Vides JP, Vicente Sobrinho LS, et al. Occurrence of leishmaniasis in cats from endemic area for visceral leishmaniasis. BrazJ Vet Res Anim Sci 2010; 47(3): 213-217.

Courtenay O, Quinnell RJ, Garcez LM, Shaw JJ, Dye C. Infectiousness in a cohort of brazilian dogs: why culling fails to control visceral leishmaniasis in areas of high transmission. J Infect Dis 2002; 186(9): 1314-1320. http://dx.doi.org/10.1086/344312. PMid:12402201.

Curi NHA, Miranda I, Talamoni SA. Serologic evidence of Leishmania infection in free-ranging wild and domestic canids around a Brazilian National Park. Mem Inst Oswaldo Cruz 2006; 101(1): 99-101. http:// dx.doi.org/10.1590/S0074-02762006000100019. PMid:16699717.

Deane L, Deane G. Estudos sobre a leishmaniose visceral americana. O Hospital 1937; 12(2): 189-199.

Deane LM, Deane MP. Visceral leishmaniasis in Brazil: geographical distribution and transmission. Rev Inst Med Trop Sao Paulo 1962; 4(1): 198-212. PMid:13884626.

Duarte A, Castro I, Fonseca IMP, Almeida V, Carvalho LM, Meireles J, et al. Survey of infectious and parasitic diseases in stray cats at the Lisbon Metropolitan Area, Portugal. J Feline Med Surg 2010; 12(6): $441-$ 446. http://dx.doi.org/10.1016/j.jfms.2009.11.003. PMid:20466573.

Feitosa MAC, Julião GR, Costa MDP, Belém B, Pessoa FAC. Diversity of sand flies in domiciliary environment of Santarém, state of Pará, Brazil: species composition and abundance patterns in rural and urban 
areas. Acta Amazon 2012; 42(4): 507-514. http://dx.doi.org/10.1590/ S0044-59672012000400008.

Ferreira EDC, Lana M, Carneiro M, Reis AB, Paes DV, Silva ESD, et al. Comparison of serological assays for the diagnosis of canine visceral leishmaniasis in animals presenting different clinical manifestations. Vet Parasitol 2007; 146(3-4): 235-241. http://dx.doi.org/10.1016/j. vetpar.2007.02.015. PMid:17403582.

Ferreira JVS, Santos TV, Santos EM, Gorayeb IS. Phlebotomine sand flies (Diptera: Psychodidae) in forest fragments of Belém metropolitan area, Pará State, Brazil, with considerations on vectors of American cutaneous leishmaniasis agents. Rev Pan-Amaz Saude 2014; 5(2): 29-35. http:// dx.doi.org/10.5123/S2176-62232014000200004.

Ferrer L, Aisa MJ, Roura X, Portús M. Serological diagnosis and treatment of canine leishmaniasis. Vet Rec 1995; 136(20): 514-516. http://dx.doi. org/10.1136/vr.136.20.514. PMid:7660549.

Figueiredo FB, Bonna IC, Nascimento LD, Costa T, Baptista C, Pacheco TM, et al. Serological evaluation for detection of anti-Leishmania antibodies in dogs and cats in the district of Santa Rita de Cássia, municipality of Barra Mansa, State of Rio de Janeiro. Rev Soc Bras Med Trop 2009; 42(2): 141-145. PMid:19448930.

Garcez LM, Cardoso JF, Chagas AP, Miranda JFC, Souza GCR, Soares DC, et al. Vigilância da leishmaniose visceral em localidades epidemiologicamente distintas em Juruti, um município minerário do Estado do Pará, Brasil. Rev Pan-Amaz Saúde 2010; 1(1): 107-116.

Garcez LM, Silveira FT, El Harith A, Lainson R, Shaw JJ. Experimental cutaneous leishmaniasis: IV. The humoral response of Cebus apella (Primates: Cebidae) to infections of Leishmania (Leishmania) amazonensis, L. (Viannia) lainsoni and L. (V.) braziliensis using the direct agglutination test. Acta Trop 1997; 68(1): 65-76. http://dx.doi.org/10.1016/S0001706X(97)00078-8. PMid:9352003.

Garrido JMCBG. Contribuição para o estudo da prevalência da infecção por Leishmania infantum em gatos domésticos e errantes nos distritos de Lisboa e Viseu [Dissertation]. Lisboa: Faculdade de Medicina Veterinária, Universidade Técnica de Lisboa; 2012.

Gomes APS, Cordeiro RLR. Reação cruzada no diagnóstico sorológico de leishmaniose canina. Rev Bras Parasitol Vet 2004; 23(S1): 238.

Gramiccia M, Gradoni L. The current status of zoonotic leishmaniases and approaches to disease control. Int J Parasitol 2005; 35(11-12): 11691180. http://dx.doi.org/10.1016/j.ijpara.2005.07.001. PMid:16162348.

Gramiccia M. Recent advances in leishmaniosis in pet animals: epidemiology, diagnostics and anti-vectorial prophylaxis. Vet Parasitol 2011; 181(1): 2330. http://dx.doi.org/10.1016/j.vetpar.2011.04.019. PMid:21570192.

Kirkpatrick CE, Farrell JP, Goldschmidt MH. Leishmania chagasi and L. donovani: experimental infections in domestic cats. Exp Parasitol 1984; 58(2): 125-131. http://dx.doi.org/10.1016/0014-4894(84)90027-4. PMid:6479284.

Lonardoni MVC, Bernal FHZ, Silveira TGV, Antunes V, Teodoro U, Jorge FA, et al. Comparação entre imunofluorescência indireta e aglutinação direta para o diagnóstico sorológico da leishmaniose tegumentar americana em cáes errantes. Arq Bras Med Vet Zootec 2006; 58(6): 1001-1008. http:// dx.doi.org/10.1590/S0102-09352006000600005.

Luciano RM, Lucheis SB, Troncarelli MZ, Luciano DM, Langoni H. Avaliação da reatividade cruzada entre antígenos de Leishmania spp e Trypanosoma cruzi na resposta sorológica de cães pela técnica de imunofluorescência indireta (RIFI). Braz J Vet Res Anim Sci 2009; 46(3): 181-187.
Maia C, Campino L. Can domestic cats be considered reservoir hosts of zoonotic leishmaniasis? Trends Parasitol 2011; 27(8): 341-344. http:// dx.doi.org/10.1016/j.pt.2011.03.008. PMid:21570915.

Maia C, Gomes J, Cristóvão J, Nunes M, Martins A, Rebêlo E, et al. Feline Leishmania infection in a canine leishmaniasis endemic region, Portugal. Vet Parasitol 2010; 174(3-4): 336-340. http://dx.doi.org/10.1016/j. vetpar.2010.08.030. PMid:20869810.

Mancianti F, Pedonese F, Poli A. Evaluation of dot enzyme-linked immunosorbent assay (dot-ELISA) for the serodiagnosis of canine leishmaniosis as compared with indirect immunofluorescence assay. Vet Parasitol 1996; 65(1-2): 1-9. http://dx.doi.org/10.1016/03044017(96)00946-6. PMid:8916395.

Mancianti F. Feline leishmaniasis: what's the epidemiological role of the cat? Parassitologia 2004; 46(1-2): 203-206. PMid:15305717.

Marodin NB. Estudo da avaliação laboratorial e ocorrência da infecção pela Leishmania spp. nos felinos domésticos de uma região periurbana Distrito Federal [Dissertation]. Brasília: Faculdade de Agronomia e Medicina Veterinária, Universidade de Brasília; 2011.

Martín-Sánchez JC, Acedo M, Muñoz-Pérez M, Pesson B, Marchal O, Morillas-Márquez F. Infection by Leishmania infantum in cats: epidemiological study in Spain. Vet Parasitol 2007; 145(3-4): 267-273. http://dx.doi.org/10.1016/j.vetpar.2006.11.005. PMid:17157440.

Mikaeili F, Fakhar M, Sarkari B, Motazedian MH, Hatam G. Comparison of serological methods (ELISA, DAT and IFA) for diagnosis of visceral leishmaniasis utilizing an endemic strain. Iran J Immunol 2007; 4(2): 116-121. PMid:17652852.

Mohebali M, Edrissian GH, Shirzadi MR, Akhoundi B, Hajjaran H, Zarei $Z$, et al. An observational study on the current distribution of visceral leishmaniasis in different geographical zones of Iran and implication to health policy. Travel Med Infect Dis 2011; 9(2): 67-74. http://dx.doi. org/10.1016/j.tmaid.2011.02.003. PMid:21419708.

Noé P. Research of Leishmania sp. infection in cats (Felis domesticus) from Campo Grande, MS, Brazil [Dissertation]. Campo Grande: Faculdade de Medicina Veterinária, Zootecnia Universidade Federal de Mato Grosso do Sul; 2008.

Poli A, Abramo F, Barsotti P, Leva S, Gramiccia M, Ludovisi A, et al. Feline leishmaniosis due to Leishmania infantum in Italy. Vet Parasitol 2002; 106(3): 181-191. http://dx.doi.org/10.1016/S0304-4017(02)00081-X. PMid:12062507.

Quinnell RJ, Courtenay O, Garcez LM, Kaye PM, Shaw MA, Dye $\mathrm{C}$, et al. IgG subclass responses in a longitudinal study of canine visceral leishmaniasis. Vet Immunol Immunopathol 2003; 91(3-4): 161-168. http://dx.doi.org/10.1016/S0165-2427(02)00311-2. PMid:12586479.

Rosa NJGC. Rastreio de Dirofilariose e de Leishmaniose em gatos da área metropolitana de Lisboa [Dissertation]. Lisboa: Faculdade de Medicina Veterinária, Universidade Técnica de Lisboa; 2009.

Rossi CN. Ocorrência de Leishmania sp. em gatos do município de Araçatuba - São Paulo - Brasil [Dissertation]. Jaboticabal: Faculdade de Ciências Agrárias e Veterinárias, Universidade Estadual Paulista; 2007.

SAS Institute - SAS. SAS/STAT user's guide. Version 9.3. Cary: SAS Institute Inc.; 2011.

Savani ESMM, Camargo MCGO, Carvalho MR, Zampieri RA, Santos MG, D'Auria SRN, et al. The first record in the Americas of an autochthonous case of Leishmania (Leishmania) infantum chagasi in a domestic cat (Felix catus) from Cotia County, Sao Paulo State, Brazil. 
Vet Parasitol 2004; 120(3): 229-233. http://dx.doi.org/10.1016/j. vetpar.2004.01.008. PMid:15041097.

Schallig HDFH, Schoone GJ, Beijer EGM, Kroon CCM, Hommers M, Özbel Y, et al. Development of a fast agglutination screening test (FAST) for the detection of anti-Leishmania antibodies in dogs. Vet Parasitol 2002; 109(1-2): 1-8. http://dx.doi.org/10.1016/S0304-4017(02)00268-6. PMid:12383620.

Schwanke K, Silva AMM, Pacheco A, Bahia M, Silveira FT, Scofield A, et al. Molecular diagnosis and frequency of anti-Leishmania infantum chagasi antibodies in dogs in Belém/Pará, Brazil. Pesqui Vet Bras 2014; 34(3): 255-260. http://dx.doi.org/10.1590/S0100-736X2014000300010.

Sergent E, Lombard J, Quilichini M. La leishmaniose à Alger: infection simultanée d'un enfant, d'un chien et d'un chat dans la même habitation. Bull Soc Pathol Exot 1912; 5: 93-98.

Silva AV, Cândido CDS, Pereira DP, Brazil RP, Carreira JC. The first record of american visceral leishmaniasis in domestic cats from Rio de Janeiro, Brazil. Acta Trop 2008; 105(1): 92-94. http://dx.doi.org/10.1016/j. actatropica.2007.09.001. PMid:17953938.

Silveira OJ No. Otimização de ensaios de PCR para a deteç̧âo especifica de Leishmania chagasi [Dissertation]. Goiás: Universidade Federal de Goiânia; 2010.
Simóes-Mattos L, Mattos MRF, Teixeira MJ, Oliveira-Lima JW, Bevilaqua CML, Prata-Júnior RC, et al. The susceptibility of domestic cats (Felis catus) to experimental infection with Leishmania braziliensis. Vet Parasitol 2005; 127(3-4): 199-208. http://dx.doi.org/10.1016/j.vetpar.2004.10.008. PMid:15710520.

Thrusfield M. Veterinary epidemiology. Oxford: Blackwell Science; 2007.

Uchôa CMA, Serra CMB, Duarte R, Magalhães CM, Silva RM, Theophilo F, et al. Aspectos sorológicos e epidemiológicos da leishmaniose tegumentar americana canina em Maricá, Rio de Janeiro, Brasil. Rev Soc Bras Med Trop 2001; 34(6): 563-568. http://dx.doi.org/10.1590/S003786822001000600011 . PMid:11813064.

Valadas S, Minervino AH, Lima VM, Soares RM, Ortolani EL, Gennari SM. Occurrence of antibodies anti-Neospora caninum, anti-Toxoplasma gondii, and anti-Leishmania chagasi in serum of dogs from Pará State, Amazon, Brazil. Parasitol Res 2010; 107(2): 453-457. http://dx.doi. org/10.1007/s00436-010-1890-2. PMid:20445991.

Vexenat ADC, Santana JM, Teixeira AR. Cross-reactivity of antibodies in human infections by the kinetoplastid protozoa Trypanosoma cruzi, Leishmania chagasi and Leishmania (Viannia) braziliensis. Rev Inst Med Trop Sao Paulo 1996; 38(3): 177-185. http://dx.doi.org/10.1590/S003646651996000300003. PMid:9163981. 